\title{
The effect of meat and bone meal (MBM) on the nitrogen and phosphorus content and $\mathrm{pH}$ of soil
}

\author{
Anna Nogalska ${ }^{1}$, Sławomir J. Krzebietke ${ }^{1}$, Marta Zalewska ${ }^{1}$ and Zenon Nogalski ${ }^{2}$ \\ ${ }^{1}$ Department of Agricultural Chemistry and Environmental Protection, ${ }^{2}$ Department of Cattle Breeding and Milk Evaluation, \\ University of Warmia and Mazury in Olsztyn, 10-719 Olsztyn, Poland \\ e-mail: anna.nogalska@uwm.edu.pl
}

\begin{abstract}
A field experiment was conducted in 2011-2013 in Poland. The objective of this study was to determine the effect of increasing doses of meat and bone meal (MBM) on the mineral nitrogen $\left(\mathrm{N}_{\min }\right)$ and available phosphorus $(\mathrm{P})$ content of soil and the soil $\mathrm{pH}$. Changes in the content of $\mathrm{NH}_{4}{ }^{+}-\mathrm{N}, \mathrm{NO}_{3}{ }^{-} \mathrm{N}$ and available $\mathrm{P}$ in soil were affected by MBM dose, weather conditions and crop species. Soil samples were collected each year after the growing season of the main crop. Soil amended with MBM was more abundant in mineral $\mathrm{N}$ and available $\mathrm{P}$. The lowest concentration of $\mathrm{NO}_{3}{ }^{-}-\mathrm{N}$ and the highest concentration of $\mathrm{NH}_{4}{ }^{+}-\mathrm{N}$ were noted in the first year of the study. Such low nitrate concentrations in soil resulted from the highest $\mathrm{N}$ uptake by maize, and heavy rainfall in July and August which could contribute to nitrate leaching through the soil profile. MBM had no influence on the accumulation of $\mathrm{N}_{\min }$ in soil, whereas the concentration of available $\mathrm{P}$ in soil increased significantly throughout the experiment. The soil $\mathrm{pH}$ decreased with increasing MBM doses. After the application of the highest MBM doses, soil pH classification was changed from neutral to slightly acidic.
\end{abstract}

Key words: animal meal, soil properties, $\mathrm{N}$ and $\mathrm{P}$ balance and utilization

\section{Introduction}

Agricultural utilization and processing of animal by-products (Jeng et al. 2004, 2006, Chen et al. 2011, Brod et al. 2012, Bøen and Haraldsen 2013, Kivelä et al. 2015) and other organic wastes (Hanč et al. 2008, Kalembasa and Symanowicz 2012) are important economic and environmental issues. Nutrients recovered from organic waste can be recycled back into the agricultural production, which contributes to rational use of non-renewable resources (Torri et al. 2017).

From an ecological perspective, control of the inflow and outflow of biogenic elements such as $\mathrm{N}$ and $\mathrm{P}$ is an important consideration for preserving natural environmental conditions. Too high levels of mineral $\mathrm{N}$, in particular nitrates, which remain in soil after harvest may lead to soil and groundwater contamination (Fotyma et al. 2005). During the mineralization of organic substances from MBM, some nutrients are released immediately whereas others (in particular N) are temporarily immobilized by soil microbes, which partially prevents N losses. In MBM, $\mathrm{N}$ is present in the form of protein compounds, and it is gradually released into the soil through mineralization, becoming available to plants already in the first year after application (Jeng et al. 2004, Jeng and Vagstad 2009, Nogalska 2013). Phosphorus is present in organic form (meat fraction), which can be used by plants after mineralization, and in the form of apatite (bone fraction). The release of available $P$ from apatite requires the presence of hydrogen ions $\left(\mathrm{H}^{+}\right)$(Jeng et al. 2006, Ylivainio et al. 2008).

MBM can be a viable alternative to mineral nitrogen-phosphorus fertilizers on account on its high content of $\mathrm{N}$ (approx. $80 \mathrm{~g} \mathrm{~kg}^{-1}$ ), P (approx. $50 \mathrm{~g} \mathrm{~kg}^{-1}$ ) and calcium (approx. $100 \mathrm{~g} \mathrm{~kg}^{-1}$ ) as well as micronutrients and organic matter. The results of previous studies investigating the effects of MBM, in particular its doses, on soil properties are contradictory (Valenzuela et al. 2000, Jeng and Vagstadt 2009, Brod et al. 2012, Bøen and Haraldsen 2013, Nogalska 2013, Nogalska and Zalewska 2013). The results of multi-year field experiments can provide more reliable results as chemistry and productivity of arable soils change slowly. Therefore, the present study was undertaken to determine the effect of increasing doses of MBM on the mineral $\mathrm{N}$ and available $\mathrm{P}$ content of soil and the soil $\mathrm{pH}$ in a field experiment involving a three-year crop rotation scheme. In addition, the $\mathrm{N}$ and $\mathrm{P}$ balance in soil and $\mathrm{N}$ and $\mathrm{P}$ utilization by the crops were calculated. The results pertaining to grain yield and quality and NP uptake were reported in earlier studies (Nogalska et al. 2012, Nogalska 2016). 


\section{Materials and methods \\ Field experiment}

A field experiment was carried out in 2011-2013 at the Agricultural Experiment Station in Bałdy, owned by the University of Warmia and Mazury in Olsztyn (north-eastern Poland). A two-factorial experiment was performed in a randomized block design with four replications, on soil that was classified as Haplic Cambisols according to the FAO (2014) and had the texture of loamy sand. The soil pH was neutral ( $\mathrm{pH}$ in $1 \mathrm{M} \mathrm{KCl}=6.64)$ and the content of total $\mathrm{N}$ and mineral $\mathrm{N}$ was $0.90 \mathrm{~g} \mathrm{~kg}^{-1}$ and $9.15 \mathrm{mg} \mathrm{kg}^{-1}$, respectively. The concentrations of available nutrients in soil were as follows: $\mathrm{P}-61.0 \mathrm{mg} \mathrm{kg}^{-1}$ (moderate), $\mathrm{K}-98.4 \mathrm{mg} \mathrm{kg}^{-1}$ (moderate), $\mathrm{Mg}-28.0 \mathrm{mg} \mathrm{kg}^{-1}$ (low). The soil nutrient statuses of low and moderate are based on Polish classification system. Plot size was $20 \mathrm{~m}^{2}$. The following three-year crop rotation sequence was applied: maize grown for grain, spring barley, spring barley grown for fodder. The effect of increasing MBM doses: 0 (no fertilization), 1.0, 1.5, 2.0 and $2.5 \mathrm{Mg} \mathrm{ha}^{-1}$ year $^{-1}$ (Table 1) was compared with that of NPK fertilizers applied in the control treatment (recommended mineral fertilizer rates for the tested crop species). In the treatment with mineral fertilization, $\mathrm{N}$ was applied as urea (460 $\left.\mathrm{g} \mathrm{kg}^{-1} \mathrm{~N}\right)$ or ammonium nitrate $\left(340 \mathrm{~g} \mathrm{~kg}^{-1} \mathrm{~N}\right)$, and $\mathrm{P}$ - as granular triple superphosphate $\left(201 \mathrm{~g} \mathrm{~kg}^{-1} \mathrm{P}\right)$. MBM had low potassium content (3.4 kg K per ton of MBM), which is why each year MBM was supplemented with potassium in the form of potash salt ( $498 \mathrm{~g} \mathrm{~kg}^{-1} \mathrm{~K}$ ), at the rate corresponding to potassium fertilizer levels in the control treatment. MBM contained on average $960 \mathrm{~g} \mathrm{~kg}^{-1} \mathrm{DM}, 710 \mathrm{~g} \mathrm{~kg}^{-1}$ organic matter, $280 \mathrm{~g} \mathrm{~kg}^{-1}$ crude ash, $136.9 \mathrm{~g} \mathrm{~kg}^{-1} \mathrm{crude}$ fat, $78.8 \mathrm{~g}$ $\mathrm{kg}^{-1} \mathrm{~N}, 46.7 \mathrm{~g} \mathrm{~kg}^{-1} \mathrm{P}, 3.42 \mathrm{~g} \mathrm{~kg}^{-1} \mathrm{~K}, 100.3 \mathrm{~g} \mathrm{~kg}^{-1} \mathrm{Ca}, 6.8 \mathrm{~g} \mathrm{~kg}^{-1} \mathrm{Na}$, and $2.0 \mathrm{~g} \mathrm{~kg}^{-1} \mathrm{DM} \mathrm{Mg}$. According to the Regulation of the Ministry of Agriculture and Rural Development of 7 December 2004, the MBM used in this study was lowrisk material (category 3 ) which comprises animal by-products derived from the production of products intended for human consumption. It was purchased from the Animal By-Products Disposal Plant Saria Poland in Długi Borek near Szczytno.

Table 1. Doses $\left(\mathrm{kg} \mathrm{ha}^{-1}\right.$ ) of nitrogen $(\mathrm{N})$, phosphorus $(\mathrm{P})$ and potassium $(\mathrm{K})$ applied with meat and bone meal (MBM) and mineral fertilizer rates in a four-year crop rotation

\begin{tabular}{|c|c|c|c|c|c|c|c|c|c|c|c|c|}
\hline \multirow[t]{2}{*}{ Treatment } & \multicolumn{3}{|c|}{$\begin{array}{c}2010 \text { Maize } \\
\text { (preceding crop) }\end{array}$} & \multicolumn{3}{|c|}{2011 Maize } & \multicolumn{3}{|c|}{2012 Spring barley } & \multicolumn{3}{|c|}{2013 Spring barley } \\
\hline & $\mathrm{N}$ & $\mathrm{P}$ & $\mathrm{K}$ & $\mathrm{N}$ & $\mathrm{P}$ & $\mathrm{K}$ & $\mathrm{N}$ & $\mathrm{P}$ & $\mathrm{K}$ & $\mathrm{N}$ & $\mathrm{P}$ & $\mathrm{K}$ \\
\hline 0 (no fertilizer) & 0 & 0 & 0 & 0 & 0 & 0 & 0 & 0 & 0 & 0 & 0 & 0 \\
\hline Control NPK & 160 & 40 & 140 & 160 & 40 & 140 & 100 & 40 & 110 & 100 & 40 & 110 \\
\hline 1.5 Mg MBM+K & 118 & 70 & 145 & 118 & 70 & 145 & 118 & 70 & 115 & 118 & 70 & 115 \\
\hline 2.0 Mg MBM+K & 158 & 93 & 147 & 158 & 93 & 147 & 158 & 93 & 117 & 158 & 93 & 117 \\
\hline $2.5 \mathrm{Mg} \mathrm{MBM}+\mathrm{K}$ & 197 & 117 & 149 & 197 & 117 & 149 & 197 & 117 & 118 & 197 & 117 & 118 \\
\hline
\end{tabular}

$\mathrm{NPK}=$ mineral fertilization; $\mathrm{MBM}+\mathrm{K}=$ meat and bone meal with potassium mineral fertilization as in the control NPK treatment

\section{Soil analysis}

Before the establishment of the experiment soil samples were collected at a depth of $0-30 \mathrm{~cm}$ to determine: $\mathrm{pH}$ in $1 \mathrm{M} \mathrm{KCl}$ (soil: solution extraction ratio $1: 2.5 \mathrm{v} \mathrm{v}^{-1}$ ) by the potentiometric method, content of total $\mathrm{N}$ by the Kjeldahl' method (soil: solution extraction ratio $1: 20 \mathrm{~m} \mathrm{v}^{-1}$ ), content of ammonium $\mathrm{N}$ and nitrate $\mathrm{N}$ in fresh samples after extraction with $0.06 \mathrm{M} \mathrm{K}_{2} \mathrm{SO}_{4}$ - colorimetrically $\left(\mathrm{NH}_{4}^{+}-\mathrm{N}\right.$ - with Nessler's reagent, $\mathrm{NO}_{3}^{-}-\mathrm{N}-$ with phenoldisulfonic acid; soil: solution extraction ratio 1:5 m v v $^{-1}$, available $\mathrm{P}$ and $\mathrm{K}$ - by the Egner-Riehm DL method (soil: solution extraction ratio 1:50 $\mathrm{m} \mathrm{v}^{-1}$ ), and available $\mathrm{Mg}$ - by the atomic absorption spectrometry (AAS) (soil: solution extraction ratio $1: 10 \mathrm{~m} \mathrm{v}^{-1}$ ) (Panak 1997).

Each year after harvest (maize - 21 September 2011; spring barley - 18 August 2012 and 17 August 2013), soil samples were collected at a depth of $0-30 \mathrm{~cm}$ and same analyses were conducted as at the beginning of the experiment. 


\title{
Statistical analysis
}

The results were processed statistically by analysis of variance (ANOVA) in the STATISTICA 10 program (StatSoft 2010). Experimental factor 1 was MBM dose, and experimental factor 2 was the year of the study (three years). The significance of differences between means was determined by Duncan's test at $p<0.05$.

\section{Weather conditions}

In the first two years of the study (2011 and 2012), mean monthly temperatures during the growing season were considerably higher (by 2.4 and $1.8^{\circ} \mathrm{C}$ on average) than the long-term average (1981-2010), and in the third year (2013) they were comparable with multiannual mean temperatures (Table 2). The distribution of rainfall was uneven throughout the experiment, and total precipitation was higher than the long-term average. Maize was sown in the first year of the study (on 9 May 2011). The distribution of temperatures and rainfall was conducive to the growth and development of maize, and rainfall excess was noted only in July when monthly precipitation was 2.5fold higher than the long-term average. Spring barley was grown in the second and third year of the study (2012 and 2013). Under the climatic conditions of Poland, the optimum time for sowing spring barley is the last ten days of March and the first ten days of April. In April 2012, monthly rainfall was 3-fold higher than the long-term average of 1981-2010. Precipitation excess at the beginning of April delayed sowing, which took place on 18 April 2012. After sowing, heavy rainfall and high air temperature in the last ten days of April led to the formation of soil crust, which resulted in thin and uneven stands. High ambient temperatures during the growing season, accompanied by heavy rainfall in June, promoted the development of fungal pathogens on barley, which decreased grain yield. In the third year of the study (2013), spring barley was sown on 19 April to maintain similar sowing dates. The distribution of temperatures and rainfall (except for the wet July) was comparable with the long-term average (1981-2010), which increased spring barley yield in 2013.

Table 2. Weather conditions in the growing seasons of 2011-2013, and in the 1981-2010 reference period according to the Research Station in Tomaszkowo, Poland

\begin{tabular}{|c|c|c|c|c|c|c|c|c|}
\hline \multirow[t]{2}{*}{ Month } & \multicolumn{4}{|c|}{ Average monthly temperature $\left({ }^{\circ} \mathrm{C}\right)$} & \multicolumn{4}{|c|}{ Monthly rainfall (mm) } \\
\hline & 2011 & 2012 & 2013 & 1981-2010 & 2011 & 2012 & 2013 & 1981-2010 \\
\hline April & 10.8 & 9.1 & 5.9 & 7.7 & 48.4 & 100.0 & 28.5 & 33.3 \\
\hline May & 15.7 & 16.4 & 14.8 & 13.5 & 61.4 & 68.4 & 54.5 & 58.5 \\
\hline June & 20.4 & 17.9 & 17.5 & 16.1 & 68.0 & 105.2 & 61.2 & 80.4 \\
\hline July & 20.7 & 21.6 & 18.0 & 18.7 & 184.8 & 61.8 & 121.9 & 74.2 \\
\hline August & 19.8 & 19.3 & 17.4 & 17.9 & 64.8 & 34.0 & 37.6 & 59.4 \\
\hline September & 14.2 & 13.6 & 11.3 & 12.8 & 31.2 & 38.2 & 101.1 & 56.9 \\
\hline Mean & 16.9 & 16.3 & 14.2 & 14.5 & 76.4 & 67.9 & 67.5 & 60.5 \\
\hline
\end{tabular}

\section{Results and discussion}

\author{
Mineral nitrogen
}

A statistical analysis of results (Duncan's test, $p<0.05)$ revealed that both increasing MBM doses $(1.0,1.5,2.0,2.5$ $\mathrm{Mg} \mathrm{ha}^{-1}$ ) and the duration of the experiment (three years) had significant effects on the mineral $\mathrm{N}$ content of soil in autumn (Table 3). Regardless of dose, the application of MBM significantly increased the ammonium $\mathrm{N}^{\left(\mathrm{NH}_{4}^{+}-\right.}$ $\mathrm{N}$ ) content of soil, compared with the NPK treatment. Lower doses of MBM (1.0 and $\left.1.5 \mathrm{Mg} \mathrm{ha}{ }^{-1}\right)$ exerted similar effects, increasing the concentration of $\mathrm{NH}_{4}{ }^{+}-\mathrm{N}$ in soil by approximately $25 \%$. Higher doses of MBM (2.0 and 2.5 $\mathrm{Mg} \mathrm{ha}^{-1}$ ) contributed to a 1.5 -fold increase in ammonium $\mathrm{N}$, relative to the $\mathrm{NPK}$ treatment. The abundance of $\mathrm{NH}_{4}^{+}{ }_{-}$ $\mathrm{N}$ in soil decreased each year, mostly due to the negative nitrogen balance in the soil with lower doses of MBM (Table 5). It should also be noted that precipitation was lowest in the last year of the study.

The nitrate $\mathrm{N}\left(\mathrm{NO}_{3}^{-}-\mathrm{N}\right)$ content of soil increased in response to increasing MBM doses (Table 3). In comparison with the NPK treatment, the concentration of nitrates in soil increased significantly after the application of MBM at $\geq$ 1.5 Mg ha-1. The application of MBM at $1.0 \mathrm{Mg}$ per year ( $\left.79 \mathrm{~kg} \mathrm{~N} \mathrm{ha}^{-1}\right)$ for three years (237 $\mathrm{kg} \mathrm{N} \mathrm{ha}^{-1}$ in total) was sufficient to increase the nitrate $\mathrm{N}$ content of soil to the level noted in the NPK treatment where soil was fertilized with $360 \mathrm{~kg} \mathrm{~N} \mathrm{ha}^{-1}$. In the first year, maize was fertilized with $160 \mathrm{~kg} \mathrm{~N} \mathrm{ha}^{-1}$, and in the second and third year, $100 \mathrm{~kg}$ $\mathrm{N} \mathrm{ha}^{-1}$ was applied to spring barley, in the form of urea $\left(460 \mathrm{~g} \mathrm{~kg}^{-1} \mathrm{~N}\right)$ or ammonium nitrate $\left(340 \mathrm{~g} \mathrm{~kg}^{-1} \mathrm{~N}\right)($ Table 1$)$. 
Significant differences in nitrate levels in soil were also found across the years of the study (Table 3). It should be stressed that only in the first year the nitrate content of soil was significantly (approx. 1.5-fold on average) higher in the NPK treatment than in MBM treatments. In comparison with the first year, nitrate concentration in soil was 3.4-fold higher in the second year and 2.4-fold higher in the third year. Nitrate levels in soil were low after the first growing season because the rate of $\mathrm{N}$ uptake was higher in maize (sown in 2011) than in spring barley, and heavy rainfall in July and August could have contributed to nitrate leaching through the soil profile.

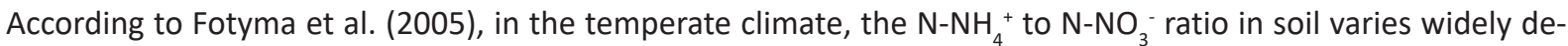
pending on the quality, agricultural suitability, biological activity, moisture content and $\mathrm{pH}$ of soil, and the rate of $\mathrm{N}$ uptake by plants. In Poland, $\mathrm{NH}_{4}^{+}-\mathrm{N}$ has a relatively high share of mineral $\mathrm{N}\left(\mathrm{N}_{\min }\right)$ in soil, ranging from 20 to $40 \%$ in autumn. In the present study, soil amendment with $\mathrm{MBM}$ increased the concentration of $\mathrm{NO}_{3}{ }^{-}-\mathrm{N} \mathrm{more}^{2}$ than two-fold relative to $\mathrm{NH}_{4}{ }^{+} \mathrm{N}$ after the third growing season, but the average levels of both $\mathrm{N}$ forms over the three-year study were comparable. Even the highest concentration of $\mathrm{NO}_{3}^{-}-\mathrm{N}$ in soil, determined in this experiment, remained within the lower range limit (Fotyma et al. 2005), which points to a low risk of environmental contamination, and confirms our previous results (Nogalska 2013) and the findings of other authors (Bohacz and Korniłłowicz-Kowalska 2005, Stępień and Wojtkowiak 2015). In the current study, soil was analyzed each year in August and September, at the end of the growing season, when $\mathrm{NO}_{3}^{-} \mathrm{-N}$ is easily leached out. Therefore, $\mathrm{MBM}$ should not be applied in early spring and late autumn (Jeng and Vagstadt 2009).

Table 3. The effect of increasing MBM doses on the mineral nitrogen content $\left(\mathrm{mg} \mathrm{kg}^{-1}\right)$ of soil

\begin{tabular}{|c|c|c|c|c|c|c|c|c|c|c|c|c|}
\hline \multirow[t]{2}{*}{ Treatment } & \multicolumn{4}{|c|}{$\mathrm{NH}_{4}^{+}-\mathrm{N}$} & \multicolumn{4}{|c|}{$\mathrm{NO}_{3}^{-}-\mathrm{N}$} & \multicolumn{4}{|c|}{$\mathrm{N}_{\min }\left(\mathrm{NH}_{4}^{+}-\mathrm{N}+\mathrm{NO}_{3}^{-}-\mathrm{N}\right)$} \\
\hline & 2011 & 2012 & 2013 & $\begin{array}{l}\text { mean } \\
\text { for dose }\end{array}$ & 2011 & 2012 & 2013 & $\begin{array}{l}\text { mean } \\
\text { for dose }\end{array}$ & 2011 & 2012 & 2013 & $\begin{array}{l}\text { mean } \\
\text { for dose }\end{array}$ \\
\hline 0 (no fertilizer) & 3.10 & 2.23 & 0.85 & $2.06^{a}$ & 1.14 & 2.51 & 1.28 & $1.64^{\mathrm{a}}$ & 4.24 & 4.74 & 2.38 & $3.70^{\mathrm{a}}$ \\
\hline Control NPK & 5.31 & 2.73 & 0.89 & $2.98^{b}$ & 2.18 & 3.07 & 2.83 & $2.69^{b}$ & 7.49 & 5.80 & 3.72 & $5.67^{b}$ \\
\hline $1.0 \mathrm{Mg} \mathrm{MBM}+\mathrm{K}$ & 6.21 & 3.04 & 1.57 & $3.61^{c}$ & 1.26 & 4.14 & 3.23 & $2.88^{b}$ & 7.47 & 7.18 & 4.80 & $6.49^{c}$ \\
\hline $1.5 \mathrm{Mg} \mathrm{MBM}+\mathrm{K}$ & 6.52 & 3.17 & 1.78 & $3.82^{\mathrm{c}}$ & 1.37 & 4.49 & 3.85 & $3.24^{c}$ & 7.89 & 7.66 & 5.63 & $7.06^{d}$ \\
\hline $2.0 \mathrm{Mg} \mathrm{MBM}+\mathrm{K}$ & 6.84 & 3.85 & 2.10 & $4.26^{d}$ & 1.41 & 7.84 & 4.41 & $4.55^{d}$ & 8.25 & 11.69 & 6.51 & $8.81^{\mathrm{e}}$ \\
\hline $2.5 \mathrm{Mg} \mathrm{MBM}+\mathrm{K}$ & 7.00 & 5.28 & 2.33 & $4.87^{\mathrm{e}}$ & 1.62 & 8.41 & 5.52 & $5.18^{\mathrm{e}}$ & 8.62 & 13.69 & 7.85 & $10.05^{f}$ \\
\hline \multirow{2}{*}{$d \times y$} & $5.83^{\mathrm{c}}$ & $3.38^{\mathrm{b}}$ & $1.59^{\mathrm{a}}$ & 3.60 & $1.50^{\mathrm{a}}$ & $5.08^{c}$ & $3.52^{\mathrm{b}}$ & 3.36 & $7.33^{\mathrm{b}}$ & $8.46^{c}$ & $5.11^{\mathrm{a}}$ & 6.96 \\
\hline & $\mathrm{s}$ & $\mathrm{s}$ & $\mathrm{s}$ & & $\mathrm{s}$ & $\mathrm{s}$ & $\mathrm{s}$ & & $\mathrm{s}$ & $\mathrm{s}$ & $\mathrm{s}$ & \\
\hline
\end{tabular}

$\mathrm{NPK}=$ mineral fertilization; $\mathrm{MBM}+\mathrm{K}=$ meat and bone meal with mineral potassium fertilizer as in the control NPK treatment; $(\mathrm{d} \times \mathrm{y})=$ interaction between MBM dose and year, $\mathrm{s}=$ significant difference at $p<0.05$.

Values within a row (mean for year) marked with different letter are significantly different at $p<0.05$.

Values within a column (mean for dose) marked with different letter are significantly different at $p<0.05$.

The mineral $\mathrm{N}\left(\mathrm{NH}_{4}{ }^{+}-\mathrm{N}+\mathrm{NO}_{3}^{-}-\mathrm{N}\right)$ content of soil increased in response to increasing MBM doses, from $3.70 \mathrm{mg} \mathrm{kg}^{-1}$ in the treatment without fertilization through $5.67 \mathrm{mg} \mathrm{kg}^{-1}$ in the NPK treatment to $10.05 \mathrm{mg} \mathrm{kg}^{-1}$ in the treatment with the highest MBM dose, and the observed differences were statistically significant (Table 3). Lower doses of MBM increased $\mathrm{N}_{\min }$ levels in soil by 15 and $25 \%$ relative to the NPK treatment, whereas higher doses - by 55 and $77 \%$. It should be stressed that the annual application of MBM had no significant effect on the accumulation of $\mathrm{N}_{\min }$ in soil. The highest abundance of mineral $\mathrm{N}$ in soil in the second year of the study most probably resulted from the lowest $\mathrm{N}$ uptake by spring barley (over two-fold lower compared with the first and third year). In the first year (2011), N uptake by maize was $183.5 \mathrm{~kg} \mathrm{ha}^{-1}$ on average (Nogalska et al. 2012), whereas in 2012 and 2013, N uptake by spring barley was 83.5 and $174.7 \mathrm{~kg} \mathrm{ha}^{-1}$, respectively (Nogalska 2016).

\section{Soil $\mathrm{pH}$}

At the beginning of the experiment, the soil pH was neutral $\left(\mathrm{pH}_{\mathrm{KCl}}=6.64\right)$. Three-year application of increasing MBM doses decreased the soil $\mathrm{pH}$ which reached $\mathrm{pH}_{\mathrm{KCl}}=6.53$ on average in the last year, and was classified as slightly acidic (Table 4). In comparison with mineral fertilizers, higher doses of MBM (i.e. 2.0 and $2.5 \mathrm{Mg} \mathrm{ha}^{-1}$ ) significantly lowered the soil pH despite the supply of considerable amounts of calcium (approx. 150-250 kg Ca ha-1). This suggests that the acidifying effect of ammonia released from MBM was stronger than the buffering effect of calcium 
(Nogalska and Zalewska 2013). Soil acidification could also result from the activity of nitrifying microorganisms whose growth is stimulated by the application of organic wastes, and high sulfate concentrations (Bohacz and Korniłowicz-Kowalska 2005). Foereid (2017) found that the pH level of soil did not affect the availability of P from the tested organic products. The findings of other authors are contradictory due to a variety of factors such as soil type, dose and type of animal wastes, and weather conditions (Valenzuela et al. 2000, Svoboda et al. 2010, Brod et al. 2012, Bøen and Haraldsen 2013).

\section{Available phosphorus}

After the third year of the experiment (2013), the average available P content of soil based on Egner-Riehm method increased from the initial value of $61.0 \mathrm{mg} \mathrm{kg}^{-1}$ to a very high value of $97.1 \mathrm{mg} \mathrm{kg}^{-1}$ (59\% increase) in MBM treatments (mean value for four MBM doses), and to a high value of $76.9 \mathrm{mg} \mathrm{kg}^{-1}$ (approx. $26 \%$ increase) in the NPK treatment (Table 4). $47 \mathrm{~kg} \mathrm{P}$ ha-1 $^{-1}$ was introduced into the soil with one megagram (Mg) of MBM. In comparison with mineral fertilizers, MBM contributed to a significant increase in available $\mathrm{P}$ levels, by approximately $9 \%$ in response to lower doses ( 1.0 and $1.5 \mathrm{Mg} \mathrm{ha}^{-1}$ ) and by 18 and $25 \%$ in response to higher doses ( 2.0 and $2.5 \mathrm{Mg} \mathrm{ha}^{-1}$, respectively). The soil $\mathrm{pH}$ tended to decrease with increasing MBM doses, leading to a higher content of available $P$, which is consistent with previous findings (Nogalska and Zalewska 2013). A beneficial influence of MBM on the abundance of plant-available $P$ in soil has been reported by many authors (Bohacz and Korniłłowicz-Kowalska 2005, Ylivainio et al. 2008, Brod et al. 2012).

Table 4. The effect of increasing MBM doses on the $\mathrm{pH}_{\mathrm{KCl}}$ of soil and on the available phosphorus content of soil

\begin{tabular}{|c|c|c|c|c|c|c|c|c|}
\hline \multirow[t]{2}{*}{ Treatment } & \multicolumn{4}{|c|}{$\mathrm{pH}_{\mathrm{KCl}}$} & \multicolumn{4}{|c|}{$\mathrm{P}\left(\mathrm{mg} \mathrm{kg}^{-1}\right)$} \\
\hline & 2011 & 2012 & 2013 & $\begin{array}{c}\text { mean for } \\
\text { dose }\end{array}$ & 2011 & 2012 & 2013 & $\begin{array}{c}\text { mean for } \\
\text { dose }\end{array}$ \\
\hline 0 (no fertilizer) & 6.73 & 6.74 & 6.74 & $6.74^{d}$ & 54.67 & 55.20 & 47.66 & $52.51^{\mathrm{a}}$ \\
\hline Control NPK & 6.66 & 6.67 & 6.67 & $6.67^{c}$ & 67.01 & 72.86 & 76.91 & $72.26^{\mathrm{b}}$ \\
\hline 1.0 Mg MBM+K & 6.69 & 6.70 & 6.70 & $6.70^{\text {cd }}$ & 70.31 & 77.50 & 87.52 & $78.44^{c}$ \\
\hline $1.5 \mathrm{Mg} \mathrm{MBM}+\mathrm{K}$ & 6.65 & 6.64 & 6.65 & $6.65^{c}$ & 71.10 & 77.92 & 89.17 & $79.40^{c}$ \\
\hline $2.0 \mathrm{Mg} \mathrm{MBM}+\mathrm{K}$ & 6.55 & 6.53 & 6.44 & $6.51^{\mathrm{b}}$ & 71.70 & 78.67 & 104.47 & $84.95^{d}$ \\
\hline $2.5 \mathrm{Mg} \mathrm{MBM}+\mathrm{K}$ & 6.54 & 6.42 & 6.34 & $6.43^{\mathrm{a}}$ & 78.60 & 84.30 & 107.14 & $90.01^{\mathrm{e}}$ \\
\hline Mean for year & $6.64^{\mathrm{a}}$ & $6.62^{\mathrm{ab}}$ & $6.59^{b}$ & 6.62 & $68.90^{\mathrm{a}}$ & $74.41^{b}$ & $85.48^{c}$ & 72.26 \\
\hline$d \times y$ & s & s & s & - & & s & $\mathrm{s}$ & - \\
\hline
\end{tabular}

The concentration of available $\mathrm{P}$ increased significantly throughout the experiment, leading to the accumulation of this nutrient in soil (Table 4). Maize, which was grown in the first year of the study, was characterized by the highest $P$ uptake $-39.4 \mathrm{~kg} \mathrm{ha}^{-1}$ on average (Nogalska et al. 2012). The average P uptake by spring barley, cultivated in 2012 and 2013, was 20.47 and $32.84 \mathrm{~kg} \mathrm{ha}^{-1}$ (Nogalska 2016), which provides another explanation for the higher $\mathrm{P}$ content of soil at the end of the first growing season. According to some authors (Valenzuela et al. 2000, Nogalska and Zalewska 2013), P fertilization is not recommended in the year following the application of MBM.

\section{Nitrogen and phosphorus balance}

Total $\mathrm{N}$ uptake during the three-year experiment ranged from $231 \mathrm{~kg}$ in the unfertilized treatment to $584 \mathrm{~kg}$ after the application of the highest MBM dose. Total P uptake ranged from 50 to $123 \mathrm{~kg}$ (Table 5). The increase in $\mathrm{N}$ uptake was due to higher grain yields and higher $\mathrm{N}$ concentrations in the grain. The highest doses of $\mathrm{N}$ in MBM resulted in a positive $\mathrm{N}$ balance, but $\mathrm{N}$ use efficiency was lowest in these treatments. As expected, the highest $\mathrm{N}$ deficiency $\left(-170 \mathrm{~kg} \mathrm{~N} \mathrm{ha}^{-1}\right)$ was noted in the treatment with the lowest MBM dose. Interestingly, plants grown in treatments with lower MBM doses ( 1 and $1.5 \mathrm{MBM} \mathrm{Mg} \mathrm{ha}^{-1}$ ) used $\mathrm{N}$ more efficiently than plants grown in the treatment with mineral fertilization (urea or ammonium nitrate). 
Table 5. Calculated cumulative nitrogen (N) and phosphorus (P) balance $\left(\mathrm{kg} \mathrm{ha}^{-1}\right)$ for 2011-2013

\begin{tabular}{|c|c|c|c|c|c|c|c|c|}
\hline \multirow[t]{2}{*}{ Treatment } & \multicolumn{4}{|c|}{$\mathrm{N}$} & \multicolumn{4}{|c|}{$P$} \\
\hline & dose & uptake & balance & $\begin{array}{l}\text { utilization } \\
\text { (\%) }\end{array}$ & dose & uptake & balance & $\begin{array}{c}\text { utilization } \\
\text { (\%) }\end{array}$ \\
\hline 0 (no fertilizer) & 0 & 231 & -231 & - & 0 & 50 & -50 & - \\
\hline Control NPK & 360 & 450 & -90 & 61 & 120 & 86 & 34 & 30 \\
\hline 1.0 Mg MBM+K & 237 & 407 & -170 & 74 & 141 & 85 & 56 & 25 \\
\hline $1.5 \mathrm{Mg} \mathrm{MBM+K}$ & 354 & 472 & -118 & 68 & 210 & 99 & 111 & 23 \\
\hline $2.0 \mathrm{Mg} \mathrm{MBM}+\mathrm{K}$ & 474 & 443 & 31 & 45 & 279 & 97 & 182 & 17 \\
\hline $2.5 \mathrm{Mg} \mathrm{MBM+K}$ & 591 & 584 & 7 & 60 & 351 & 123 & 228 & 21 \\
\hline
\end{tabular}

NPK = mineral fertilization; $\mathrm{MBM}=$ meat and bone meal with potassium mineral fertilization as in the control NPK treatment

A three-year $P$ balance was positive in all treatments (Table 5). The highest efficiency of $P$ utilization was observed in treatments with mineral fertilization and lower doses of MBM. It should be noted that MBM applied at the two highest doses contributed to $\mathrm{P}$ accumulation in soil (182 to $228 \mathrm{~kg} \mathrm{P} \mathrm{ha}^{-1}$ ). Phosphorus supplied by MBM, which has not been taken up by plants, can be a source of available $P$ in soil. Soil analyses revealed that the available $P$ content of soil increased significantly throughout the study (Table 4). In the last year of the experiment, i.e. after the application of MBM at 1.5 to $2.5 \mathrm{Mg} \mathrm{ha}^{-1}$ for three years, soil was abundant in available P. The pH of soil analyzed in this study was classified as neutral to slightly acidic. Under such conditions, sparingly soluble P compounds, i.e. apatite (bone fractions), are slowly converted into plant-available forms and therefore should not pose a threat to the environment. According to some authors (Valenzuela et al. 2000, Nogalska and Zalewska 2013), P fertilization is not recommended in the year following the application of MBM. This is consistent with the findings of Ylivainio et al. (2008) who demonstrated that only $20 \%$ of $\mathrm{P}$ provided by MBM was available to plants in the first year, compared with approximately 60\% three years after MBM application. However, according to Jeng et al. (2006), as much as $50 \%$ of $P$ from MBM was available to plants already in the first year. The fertilizing effect of MBM is greater in P-deficient soils (Brod et al. 2012, Kivela et al. 2015). In soil characterized by moderate levels of available $\mathrm{P}$, like the soil used in this experiment, plants can absorb $\mathrm{P}$ from soil reserves. According to Fernandes et al. (2010), high doses of MBM can lead to the accumulation of excessive P amounts in soils, particularly in acidic soils. Thus, lower doses of MBM (up to $1.5 \mathrm{Mg} \mathrm{ha}^{-1}$, as shown in the present study) supplemented with mineral $\mathrm{N}$ applied pre-sowing are safer for the environment, which corroborates the findings of Jeng et al (2004) who demonstrated that $\mathrm{N}$ supplied by MBM satisfied the $\mathrm{N}$ requirements of cereals in $80 \%$, compared with mineral fertilizers.

\section{Conclusions}

The results of this study indicate that increasing MBM doses contributed to a significant increase in the content of mineral $\mathrm{N}$ and available $\mathrm{P}$ in soil. Applied annually, MBM led to the accumulation of available P in soil, whereas such a relationship was not noted for mineral N. Since the N:P ratio of MBM is rather low, and represents more $P$ relative to $\mathrm{N}$ than the normal uptake of cereals, the treatments with $\mathrm{MBM}$ should increase the content of readily available $\mathrm{P}$ in soil. This effect was confirmed by the present field experiment. Intensive fertilization with MBM lowered the soil $\mathrm{pH}$. It can be concluded that the dose of MBM applied to plants with low $\mathrm{N}$ and $\mathrm{P}$ requirements and to spring crops grown in sequence should be appropriately selected based on the nutrient requirements of a given plant species. According to the three-year $\mathrm{N}$ and $\mathrm{P}$ balance, a dose of around $2.0 \mathrm{Mg} \mathrm{ha}^{-1} \mathrm{year}^{-1} \mathrm{MBM}$ meets the $\mathrm{N}$ requirement of the analyzed plants but contributes to a surplus of available $\mathrm{P}$ in soil. Therefore, MBM could be applied biannually in addition to mineral $\mathrm{N}$ fertilizer.

\section{Acknowledgements}

This research was supported by the Polish Ministry of Science and Higher Education as part of statutory activity, grant No. 20.610.002-300.

\section{References}

Bohacz, J. \& Korniłłowicz-Kowalska, T. 2005. Influence of keratin-bark and keratin-bark-straw composts on properties of selected soils. Part II. Chemical properties. Zeszyty Problemowe Postępów Nauk Rolniczych 506: 65-76. (in Polish).

Bøen, A. \& Haraldsen, T.K. 2013. Meat and bone meal and biosolids as slow-release phosphorus fertilizers. Agriculture and Food Science 22: 235-246. 
Brod, E., Haraldsen, T.K. \& Breland, T.A. 2012. Fertilization effects of organic waste resources and bottom wood ash: results from a pot experiment. Agricultural and Food Science 21: 332-347.

Chen, L., Kivelä, J., Helenius, J. \& Kangas, A. 2011. Meat bone meal as fertiliser for barley and oat. Agricultural and Food Science 20: 235-244. https://doi.org/10.2137/145960611797471552

FAO 2014. World Reference Base for Soil Resources. Rome, World Soil Resources Report 106. http://www.fao.org/3/a-i3794e.pdf Fernandes, R., Sempiterno, C. \& Calouro, F. 2010. Meat and bone meal as nitrogen and phosphorus supplier to ryegrass (Lolium multiflorum L. var Helen); II. Effects on soil N and P levels. In: dos Santos Cordovil M. \& Ferreira L. (eds.). Treatment and use of organic residues in Agriculture: Challenges and opportunitites towards sustainable management. 14th Ramiran International Conference Lisbon 12-15 September 2010. Universidade Técnica de Lisboa, Instituto Superior de Agronomia, Lisbon, Portugal.

Foereid, B. 2017. Phosphorus availability in residues as fertilizers in organic agriculture. Agricultural and Food Science 26: 25-33. https://doi.org/10.23986/afsci.59307

Fotyma, E., Fotyma, M. \& Pietruch, C. 2005. The content of mineral nitrogen in the soils of Poland. Fertilizers and Fertilization 2 : 41-47. (in Polish).

Hanč, A., Tlustoš, J., Száková, J. \& Balík, J. 2008. The influence of organic fertilizers application on phosphorus and potassium bioavailability. Plant, Soil and Environment 54: 2472-54.

Jeng, A.S., Haraldsen, T.K., Grønlund, A. \& Pedersen, P.A. 2006. Meat and bone meal as nitrogen and phosphorus fertilizer to cereals and ryegrass. Nutrient Cycling in Agroecosystems 76: 183-191. https://doi.org/10.1007/s10705-005-5170-y

Jeng, A.S., Haraldsen, T.K., Vagstad, N. \& Grønlund, N. 2004. Meat and bone meal as nitrogen fertilizer to cereals in Norway. Agricultural and Food Science 13: 268-275. https://doi.org/10.2137/1239099042643080

Jeng, A.S. \& Vagstad, N. 2009. Potential nitrogen and phosphorus leaching from soils fertilized with meat and bone meal. Acta Agriculturae Scandinavica, Section B-Soil \& Plant Science 59: 238-245.

Kalembasa, S. \& Symanowicz, B. 2012. Enzymatic activity of soil after applying various waste organic material, ash, and mineral fertilizers. Polish Journal of Environmental Studies 21: 1635-1641.

Kivela, J., Chen, L., Muurinen, S., Kivijarvi, P., Hintikainen, V. \& Helenius, J. 2015. Effect of meat and bone meal as fertilizer on yield and quality of sugar beet and carrot. Agricultural and Food Science 24: 68-83.

Nogalska, A. 2016. Meat and bone meal as fertilizer for spring barley. Plant, Soil and Environment 62: 373-378. https://doi.org/10.17221/270/2016-PSE

Nogalska, A. 2013. Changes in the soil nitrogen content caused by direct and residual effect of meat and bone meal. Journal of Elementology 18: 659-671.

Nogalska, A., Czapla, J., Nogalski, Z., Skwierawska, M. \& Kaszuba, M. 2012. The effect of increasing doses of meat and bone meal (MBM) on maize (Zea mays L.) grown for grain. Agricultural and Food Science 21: 325-331.

Nogalska, A. \& Zalewska, M. 2013. The effect of meat and bone meal on phosphorus concentrations in soil and crop plants. Plant, Soil and Environment 59: 575-580.

Panak, H. 1997. Metodical Guide to Agricultural Chemistry. Wydawnictwo ART Olsztyn. (in Polish).

StatSoft, Inc. 2010. Statistica (data analysis Software system), version 10. www.statsoft.com

Stępień, A. \& Wojtkowiak, K. 2015. Variability of mineral nitrogen contents in soil as affected by meat and bone meal used as fertilizer. Chilean Journal of Agricultural Research 60: 291-296.

Svoboda, J., Lošák, T., Hlušek, J., Jandák, J. \& Martinec, J. 2010. The effect of meat and bone meal fertilizers in the nutrition of potatoes and spring barley. Agrochemistry 50: 8-13.

Torri, S.I., Corrêa, R.S. \& Renella, G. 2017. Biosolid application to agricultural land-a contribution to global phosphorus recycle: A review. Pedosphere 27: 1-16. https://doi.org/10.1016/S1002-0160(15)60106-0

Valenzuela, H.R., Goo, T., Randall, H., Hamasaki, R.H. \& Radovich, T. 2000. The effect of bone meal on the yield of jicama. Pachyrhizus Erosus in Oahu Hawaii. Proceedings of the Florida State Horticultural Society 113: 222-226.

Ylivainio, K., Uusitalo, R. \& Turtola, E. 2008. Meat and bone meal and fox manure as P source for ryegrass (Lolium multiflorum) grown on a limed soil. Nutrient Cycling in Agroecosystems 81: 267-278. https://doi.org/10.1007/s10705-007-9162-y 